\title{
Binding of stallion spermatozoa to the equine zona pellucida after coculture with oviductal epithelial cells
}

\author{
J. E. Ellington ${ }^{1}$, B. A. Ball ${ }^{1, *}$ and X. Yang ${ }^{2}$ \\ Department of ${ }^{1}$ Clinical Sciences and ${ }^{2}$ Animal Science, Cornell University, Ithaca, NY 14853, USA
}

\begin{abstract}
The objective of this study was to determine whether coculture of stallion spermatozoa and mare oviductal (uterine tubal) epithelial cells induced sperm cell capacitation in vitro. Capacitation as determined by zona binding and chlortetracycline staining of the sperm cells was compared for stallion spermatozoa: (1) incubated with medium alone (negative control), (2) treated with calcium ionophore A23187 (positive control) or (3) cultured with mare oviductal epithelial cells (OEC) for $4 \mathrm{~h}$. Chlortetracycline staining patterns of sperm cells bound to the zonae were used to group spermatozoa as uncapacitated, capacitated or acrosome reacted. The zonae and attached spermatozoa were stained for evaluation after initial binding (pulse) and after $1 \mathrm{~h}$ of co-incubation (chase). More sperm cells in the ionophore and OEC treatments bound to the zonae at both the pulse and chase than in control medium $(P<0.001)$. More bound sperm cells were capacitated at the pulse, and acrosome reacted at the chase, for the ionophore and co-culture groups than for the controls $(P<0.001)$. Staining patterns for sperm cells not bound to the zona pellucida in each of the treatments differed $(P<0.05)$ from the population of sperm cells that bound to the zona pellucida. There was a higher percentage of capacitated spermatozoa and a lower percentage of acrosome-reacted spermatozoa bound to the zonae at the pulse than were represented in the treatment suspensions of sperm cells. The co-culture treatment resulted in a higher $(P<0.05)$ proportion of sperm cells in suspension with the capacitated staining pattern and a lower $(P<0.05)$ proportion with the uncapacitated pattern than those in the ionophore treatment.
\end{abstract}

\section{Introduction}

Prefertilization binding of spermatozoa to the zona pellucida is a receptor-mediated event that involves cell surface interactions of sperm cell carbohydrate-binding proteins and glycoconjugates of the zona (reviewed by Wassarman, 1988; Saling, 1989). This receptor-mediated process results in acrosome membrane exocytosis and is regulated by agonists in the zona itself (Florman and Storey, 1982). Signal transduction mediated through $G$ proteins after binding alters the internal ionic environment of the sperm cell leading to acrosome reaction and subsequent penetration of the spermatozoa into the oocyte (Florman et al., 1989).

The zona glycoprotein, ZP3, which serves as the primary sperm cell receptor and agonist for acrosome reaction has been described in mice (Bleil and Wassarman, 1980). In other mammals, the glycoconjugates of the egg and the complementary sperm cell proteins involved in binding have begun to be defined ( $\mathrm{O}^{\prime} \mathrm{Rand}$ and Fisher, 1987; Peterson and Hunt, 1989; Lathrop et al., 1990; Miller et al., 1991). Plasma membrane galactosyltransferase is thought to mediate gamete recognition in several species, including mice, cows and horses (Benau et al., 1990; Fayrer-Hosken et al., 1991). The activation or exposure of such sperm cell plasma membrane proteins is probably an integral part of capacitation.

*Reprint requests.

Received 29 June 1992.
The ability of sperm cells to bind to the zona is acquired early in the process of capacitation, and capacitation probably enhances receptor access of the sperm cell to the zona (Florman and First, 1988).

Glycosaminoglycans from the female reproductive tract bind to sperm cells during capacitation, and these substances are thought to be involved in the changes of capacitation (Lenz et al., 1983; Handrow et al., 1984; Lee et al., 1986; Voglmayr and Sawyer, 1986; Parrish et al., 1989a). It is suggested that these glycoconjugates from the female tract are involved in sperm cell capacitation in a wide range of species (Parrish et al., 1989b). The recent description of an oviductal (uterine tubal) epithelial cell (OEC) and sperm cell in vitro co-culture system offers an innovative method to investigate interactions of spermatozoa, epithelial cells and epithelial cell secretory products from one of the physiological sites of capacitation, the tubal isthmus (Nagai and Moor, 1990; Ellington et al., 1991; Pollard et al., 1991).

Capacitation of sperm cells from the stallion has proved to be difficult in vitro with only one live foal reported from in vitro fertilization. This foal was obtained through the use of A23187 ionophore-treated sperm cells (Palmer et al., 1991). The low level of success in equine sperm cell capacitation in vitro and subsequent fertilization requires investigation into alternative methods to those that have been used in the past.

In this study, we evaluated the ability of stallion sperm cells, capacitated in vitro by co-culture with $\mathrm{OEC}$, to bind to the equine zona pellucida. Induction of the acrosome reaction 
after incubation of spermatozoa and zonae together was then evaluated.

\section{Materials and Methods}

\section{Recovery of zonae pellucidae}

Ovaries from mares during the breeding season were collected at the abattoir and immediately frozen whole at $-20^{\circ} \mathrm{C}$ in plastic bags (Wheeler and Seidel, 1987). Follicles ranging from 1 to $20 \mathrm{~mm}$ in diameter were dissected from the ovaries, and the oocytes recovered into phosphate-buffered saline (PBS) after ovaries were thawed. Oocytes were washed in PBS and the cumulus removed by vigorous aspiration through a small bore pipette. No selection of oocytes was done as the freezing process alters the appearance of the cumulus cells. Collected oocytes were pooled from several ovaries, and stored in a modified Tyrode's solution (TALP; Padilla and Foote, 1991) at $4^{\circ} \mathrm{C}$ for less than $8 \mathrm{~h}$ or until use. Pooled oocytes were then randomly assigned across treatments to minimize zona effects.

\section{OEC monolayer production}

Epithelial cells were collected from mares two days after ovulation and cultured in 50:50 DMEM:F12 with 10\% fetal bovine serum (FBS), $10 \mathrm{ng}$ epidermal growth factor $\mathrm{ml}^{-1}, 5 \mu \mathrm{g}$ insulin $\mathrm{ml}^{-1}, 5 \mu \mathrm{g}$ transferrin $\mathrm{ml}^{-1}, 5 \mathrm{ng}$ selenium $\mathrm{ml}^{-1}, 50$ iu penicillin $\mathrm{ml}^{-1}$ and $50 \mu \mathrm{g}$ streptomycin $\mathrm{ml}^{-1}$. Confluent cells were trypsinized and frozen in 10\% dimethyl sulfoxide (DMSO) and 50\% FBS (Ellington ef al., 1992, 1993). Cells were then thawed and cultured in the above medium in $2 \mathrm{~cm}^{2}$ wells until confluent, usually $4-5$ days. All cells obtained by luminal lavage stained positively for cytokeratin, indicating their epithelial nature.

\section{Sperm cell preparation}

Freshly ejaculated sperm cells from three stallions were used in these experiments. Progressive motility of $>60 \%$ was confirmed for each ejaculate, and concentrations of sperm cells were determined. The experiment was replicated six times with one stallion being used once, one stallion used twice, and one stallion used three times. The stallion which was used only once became ill and was no longer available for the study. Sperm cells were washed by centrifugation in TALP at $300 \mathrm{~g}$ for $10 \mathrm{~min}$. Aliquots of sperm cells were then assigned to the following treatments: (a) initial control, (b) initial ionophore, (c) $4 \mathrm{~h}$ control, (d) $4 \mathrm{~h}$ ionophore, or (e) $4 \mathrm{~h}$ coculture. More specifically, control spermatozoa in TALP alone were evaluated initially or after $4 \mathrm{~h}$ of incubation. lonophore treated spermatozoa were

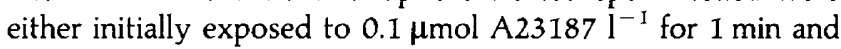
then quenched with TALP (Blue et al., 1988; Yang et al., 1992), or were incubated for $4 \mathrm{~h}$ in TALP alone and then exposed to ionophore as above. Ten million sperm cells in a total volume of $250 \mu \mathrm{l}$ TALP were used for groups (a)-(d). Approximately a quarter of the sperm cells in coculture are released from the OEC in $4 \mathrm{~h}$ (Ellington et al., 1992). Sperm cells were applied to confluent monolayers of mare OEC at 40 million spermatozoa per well to obtain similar numbers of spermatozoa in the coculture suspension at $\mathbf{4} \mathrm{h}$ of culture as in the other treatment group. After 30 min of incubation all sperm cells that had not attached to the OEC were removed and the wells were covered with fresh TALP (Ellington et al., 1992). This then allowed accumulation of a population of sperm cells that had been attached to the OEC, and had become free in suspension over the $4 \mathrm{~h}$ of co-culture.

\section{Pulse chase experiment}

All incubations were done at $38.5^{\circ} \mathrm{C}$ in $5 \% \mathrm{CO}_{2}$ and humidified air. Oocytes were added directly to wells of control, ionophore-treated or cocultured sperm cells and left for a $1 \mathrm{~min}$ pulse (Cross et al., 1988). Six oocytes from the pool were randomly assigned to each treatment group for each of the six replicates. All oocytes were then forcefully rinsed through three TALP washes using a wide bore pipette and friction against the Petri dish walls to disperse any non-bound or loosely bound spermatozoa. Half of the oocytes ( $n=3$ per replicate) were removed for evaluation by staining with chlortetracycline and the remaining half were incubated in TALP for an additional hour (chase group). At the end of this hour, these oocytes were also evaluated.

\section{Chlortetracycline staining}

A stock solution of chlortetracycline (CTC) was made each day by adding $0.0026 \mathrm{~g} \mathrm{CTC} \mathrm{powder} \mathrm{to} 10 \mathrm{ml}$ of a Tris buffer containing $20 \mathrm{mmol}$ Tris $1^{-1}, 5 \mathrm{mmol}$ cysteine $1^{-1}$ and $130 \mathrm{mmol}$ sodium chloride $\mathrm{l}^{-1}$ (Saling and Storey, 1979; Varner et al., 1987). Oocytes with bound sperm cells were placed on warmed slides in a $10 \mu \mathrm{l}$ drop of TALP and $10 \mu \mathrm{l}$ of CTC stock was layered over the oocyte (Lee and Storey, 1989). Samples were handled in the dark after this time to preserve fluorescence. The slides were incubated for $10 \mathrm{~min}$ at $38.5^{\circ} \mathrm{C}$. An $18 \mathrm{~mm}^{2}$ coverslip was placed over the oocyte and gentle pressure was applied to rupture the oocyte and to remove the intensely fluorescent cytoplasm (Saling and Storey, 1979). The zona with attached spermatozoa was then visualized under epifluorescent microscopy and categorized into four presumptive groups (Varner ef al., 1987; 1992). On the basis of membrane patterns of fluorescence, sperm cells were recorded as either uncapacitated, capacitated, acrosome reacted or unreadable. This latter group included primarily spermatozoa that were layered on top of each other and thus could not be accurately interpreted. Aliquots of treated or control sperm cell suspensions from each of the five groups were also removed before zonae addition and stained with CTC to determine the populations of sperm cells present in the treatment groups based on the membrane staining patterns of 100 spermatozoa.

\section{Experimental design}

The experiment was replicated six times. For each of the five treatments (initial and $4 \mathrm{~h}$ control, initial and $4 \mathrm{~h}$ ionophore, or $4 \mathrm{~h}$ co-culture) CTC staining was performed on (1) the suspensions of sperm cells, (2) pulse exposed zonae with attached sperm cells, and (3) chase incubated zonae with attached sperm cells. Numbers of sperm cells bound to the zonae and percentages of spermatozoa were compared in the four staining categories by an analysis of variance using the model: $y=\mathrm{ST}+\mathrm{EJ}+\mathrm{TR}+$ 


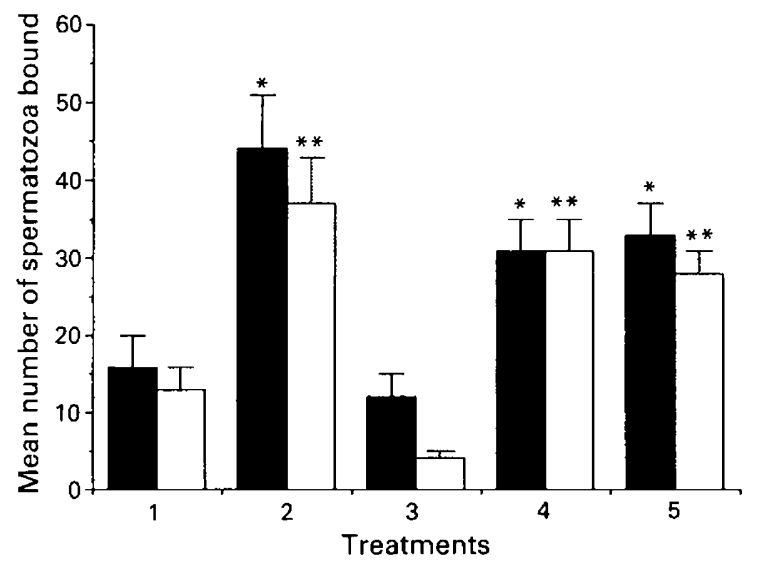

Fig. 1. Mean number \pm SEM of spermatozoa bound to zonae after $1 \mathrm{~min}$ (pulse) or after $1 \mathrm{~h}$ (chase). ( $\square$ ): pulse; $(\square)$ : chase; treatment $1=$ initial control; treatment $2=$ initial ionophore; treatment $3=4 \mathrm{~h}$ control; treatment $4=4 \mathrm{~h}$ ionophore; and treatment $5=4 \mathrm{~h}$ coculture. "Numbers significantly different from pulse control group numbers $(P<0.05)$. ${ }^{* *}$ Numbers significantly different from chase control group numbers $(P<0.05)$.

$\mathrm{PC}+\mathrm{ST}^{*} \mathrm{TR}+\mathrm{TR}^{*} \mathrm{PC}+$ error, where $\mathrm{ST}=$ stallion, $\mathrm{EJ}=$ ejaculate, $T R=$ sperm cell treatment and $P C=$ pulse or chase zona. This model was used to block treatments to take into account the stallion to stallion variability. All samples were read by the same individual who was blind to the treatment conditions of the sample. Numbers of sperm cells bound and numbers of sperm cells in the four staining categories (uncapacitated, capacitated, acrosome reacted or unreadable) were logarithmically transformed to obtain normal distributions (Neter et al., 1985). Percentage data for sperm cells in the four categories were arcsin transformed for the analysis. The staining patterns for sperm cell suspensions and sperm cells bound to zonae were also compared with treatment groups by an analysis of variance (SAS, 1982).

\section{Results}

Sperm cells attached to the OEC within minutes of addition to the co-culture wells. The mean number of sperm cells that were released from the co-culture wells and were thus in suspension during the $4 \mathrm{~h}$ of incubation was $9 \times 10^{6}$ spermatozoa (range of $\left.6-11 \times 10^{6}\right)$.

\section{Zona binding}

There were $20-25$ oocytes evaluated per group, with a total of 110 used in the study. This number varies owing to losses during the handling or staining process. Total numbers of sperm cells binding to the zonae (Fig. 1) were significantly affected by the treatment $(P<0.0005)$. The control treatments both initially and at $4 \mathrm{~h}$ had fewer bound spermatozoa than the ionophore (initial and $4 \mathrm{~h}$ ) and co-culture groups. The zonae in the chase group showed fewer $(P<0.05)$ sperm cells bound than did the pulse group, although this was not consistently true for all treatments.

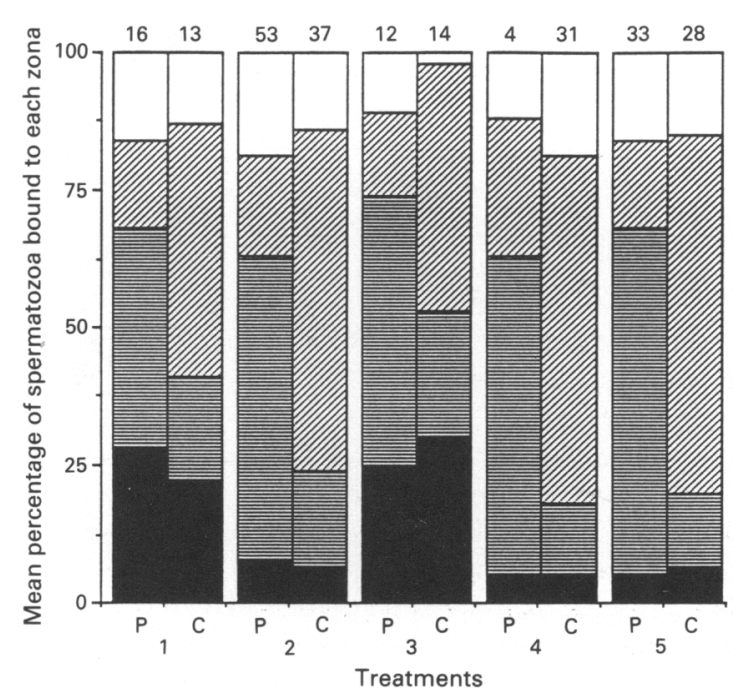

Fig. 2. Changes in membrane staining status of bound spermatozoa.

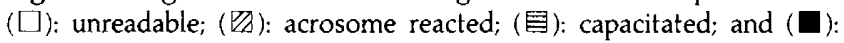
uncapacitated. $P$ : pulse and $C$ : chase; treatment $I=$ initial control; treatment $2=$ initial ionophore; treatment $3=4 \mathrm{~h}$ control; treatment $4=4 \mathrm{~h}$ ionophore; and treatment $5=4 \mathrm{~h}$ coculture.

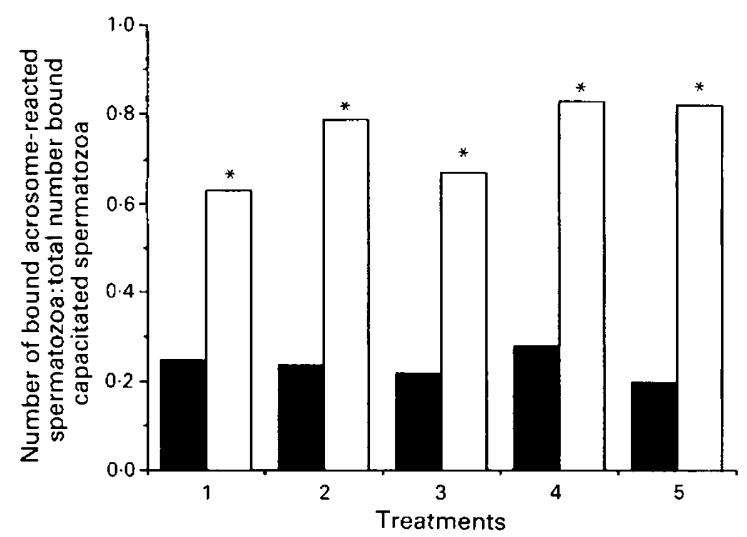

Fig. 3. Ratio of the number of bound acrosome-reacted spermatozoa to the total number of bound capacitated spermatozoa (capacitated plus acrosome reacted). ( $\square$ ): pulse; $(\square)$ : chase; treatment $I=$ initial control; treatment $2=$ initial ionophore; treatment $3=4 \mathrm{~h}$ control; treatment $4=4 \mathrm{~h}$ ionophore; and treatment $5=4 \mathrm{~h}$ coculture. ${ }^{*}$ Ratio at the 'chase' is higher than at the 'pulse' $(P<0.05)$.

The percentage of acrosome-reacted sperm cells bound was significantly affected $(P<0.0001)$ by the incubation time, e.g. pulse or chase (PC) with more spermatozoa reacted in the chase group for all groups (Figs 2 and 3). Total numbers of acrosomereacted sperm cells bound also differed between treatments, with ionophore and coculture treatment increasing $(P<0.001)$ the number of acrosome reacted sperm cells bound at both the pulse and chase over the control.

The percentage of capacitated sperm cells, as determined by CTC staining, differed ( $P<0.0001$ ) between PC for all groups with a higher percentage of capacitated spermatozoa bound in 
the pulse group. Total numbers of capacitated sperm cells bound at the pulse also differed between treatment groups $(P<0.001)$; fewer capacitated spermatozoa bound to zonae in the initial and $4 \mathrm{~h}$ control groups at both the pulse and chase.

Consistently, one to four uncapacitated sperm cells bound to each zona, irrespective of treatment group or incubation time ( $\mathrm{P}$ or $\mathrm{C})$. This percentage of uncapacitated spermatozoa was not a significant population except in the control groups which had many fewer total sperm cells bound to the zonae, where uncapacitated cells accounted for $25 \%$ of the spermatozoa bound.

The percentage of unreadable sperm cells did not differ between any of the groups with the exception of the $4 \mathrm{~h}$ control $(P<0.05)$. There were fewer total sperm cells bound in this group $(8 \pm 1.7)$ and it was therefore rare to have difficulty reading any of them.

Overall, more sperm cells were bound to zonae in the ionophore or coculture treated groups versus the control groups, but these two treated groups did not differ from each other in the total number of spermatozoa bound. Numbers of acrosomereacted and capacitated sperm cells bound also differed between the treated groups and the controls. In all treatment groups the change in the proportion of bound capacitated to bound acrosome-reacted spermatozoa was almost inversely related between the pulse and chase samples (Figs 2 and 3).

There was no effect of stallion on any of the variables with the exception of the total numbers of sperm cells bound, which did significantly differ $(P<0.002)$ between stallions. No significant stallion by treatment interactions were found.

\section{Suspensions versus bound spermatozoa}

The staining patterns of aliquots of sperm cells from suspension at $4 \mathrm{~h}$ for each of the five groups differed from each other $(P<0.0001)$ for percentage uncapacitated, capacitated and acrosome reacted. More capacitated or acrosome-reacted spermatozoa were present in the ionophore and coculture groups than in the control groups initially or at $4 \mathrm{~h}$. Furthermore, there was a higher $(P<0.05)$ percentage of capacitated and a lower $(P<0.05)$ percentage of uncapacitated spermatozoa in the cocultured group than in the ionophore-treated group at $4 \mathrm{~h}$.

A comparison of staining patterns of sperm cells in suspension with sperm cells that bound to pulse zonae within each of the five treatments showed a lower percentage $(P<0.001)$ of uncapacitated spermatozoa bound to the zonae than were present in the suspension, and a significantly higher percentage $(P<0.001)$ of capacitated sperm cells bound than the population of sperm cells in suspension for all treatment groups. With the exception of the initial control group, there was also a lower percentage $(P<0.01)$ of acrosome-reacted sperm cells bound at the pulse than was found in the suspensions at that time (Table 1).

\section{Discussion}

The results of this study show that stallion sperm cells capacitated by coculture with OEC can bind to frozen-thawed equine zona and undergo acrosome reaction. Capacitated sperm cells in
Table 1. Distribution of staining patterns for spermatozoa in suspension or bound to zonae

\begin{tabular}{|c|c|c|c|}
\hline Treatment & Uncapacitated & $\begin{array}{c}\text { Mean } \\
\text { percentage } \\
\text { of spermatozoa } \\
\text { capacitated }\end{array}$ & $\begin{array}{c}\text { Acrosome } \\
\text { reacted }\end{array}$ \\
\hline \multicolumn{4}{|l|}{ Initial control } \\
\hline Suspension & $80^{a}$ & $6^{a}$ & 14 \\
\hline Bound ${ }^{*}$ & $33^{\mathrm{b}}$ & $50^{\mathrm{b}}$ & 17 \\
\hline \multicolumn{4}{|c|}{ Initial ionophore } \\
\hline Suspension & $42^{\mathrm{a}}$ & $22^{\mathrm{a}}$ & $36^{\mathrm{a}}$ \\
\hline Bound ${ }^{*}$ & $10^{\mathrm{b}}$ & $68^{\mathrm{b}}$ & $22^{b}$ \\
\hline \multicolumn{4}{|l|}{$4 \mathrm{~h}$ control } \\
\hline Suspension & $60^{a}$ & $13^{\mathrm{a}}$ & $27^{\mathrm{a}}$ \\
\hline Bound* & $20^{\mathrm{b}}$ & $70^{\mathrm{b}}$ & $10^{\mathrm{b}}$ \\
\hline \multicolumn{4}{|l|}{$4 \mathrm{~h}$ ionophore } \\
\hline Suspension & $32^{\mathrm{a}}$ & $28^{\mathrm{a}}$ & $40^{\mathrm{a}}$ \\
\hline Bound ${ }^{*}$ & $7^{\mathrm{b}}$ & $67^{\mathrm{b}}$ & $26^{\mathrm{b}}$ \\
\hline \multicolumn{4}{|l|}{$4 \mathrm{~h}$ co-culture } \\
\hline Suspension & $17^{\mathrm{a}}$ & $53^{\mathrm{a}}$ & $30^{\mathrm{a}}$ \\
\hline Bound ${ }^{*}$ & $7^{\mathrm{b}}$ & $74^{b}$ & $19^{\mathrm{b}}$ \\
\hline
\end{tabular}

a.bSignificant difference $P<0.05$ within treatment groups. *Spermatozoa bound at the pulse.

suspension from each treatment group preferentially bound to the mare zona and many of those bound underwent acrosomal exocytosis probably triggered by a zona agonist. The coculture resulted in capacitation of spermatozoa as determined by CTC staining and zona binding, equivalent to that of ionophore treatment. This lends further evidence to the hypothesis that capacitation in vivo is regulated by sperm cell sequestration with OEC of the isthmus, and that the sperm co-culture model can be used to study these events in vitro.

Current hypotheses of fertilization state that capacitated sperm cells bind to the zona and then undergo zona-mediated acrosomal exocytosis (Saling, 1989). It has previously been shown that capacitated stallion spermatozoa do undergo agonist mediated acrosome reaction in vitro with solubilized zona products (Arns et al., 1991). In the present study, the presence of a population of sperm cells that were acrosome reacted and bound to the zona at the pulse, may be due to one of two factors. Perhaps both acrosome-intact capacitated and acrosome-reacted spermatozoa from the stallion can bind to the equine zona, as happens with both guinea-pig and human sperm cells (Morales et al., 1989; Lathrop et al., 1990). This is not the case in mice in which only acrosome-intact spermatozoa can bind to the zona (Saling and Storey, 1979). In species in which both capacitated and acrosome-reacted sperm cells bind, the relationship between the percentage of acrosome reacted sperm cells in the treatment suspension and that bound to the zona was linear (Morales et al., 1989). There was no such linear relationship of this type seen with the stallion sperm cells in this study. Perhaps only capacitated spermatozoa did bind to the equine zona, but the 10-15 min required for staining and processing of the zona with attached sperm cells allowed some spermatozoa to undergo acrosome reaction. Because acrosome-reacted sperm cells remain bound to the zona after exocytosis has occurred 
(Yanagimachi and Phillips, 1984), it is not possible using the present protocol to know clearly whether only capacitated stallion sperm cells can bind to the equine zona in vitro.

Uncapacitated sperm cells do not adhere to the bovine zona (Florman and First, 1988). However, a small number of spermatozoa manifesting the uncapacitated staining pattern did attach in this study. The percentage of uncapacitated sperm cells was very consistent between the pulse and chase groups, suggesting that these spermatozoa did not become capacitated. Perhaps these sperm cells had exposed receptor proteins for the zona but were not biochemically poised to continue the capacitation process. Another explanation may be the use of frozenthawed zonae in the study reported here. It is not known whether zona receptors function identically in fresh and frozenthawed mare zonae in terms of sperm cell binding and subsequent exocytosis. Further studies are needed to detect differences in sperm cell binding to the two types of zona.

Although the cocultured sperm cells in suspension had twice the number of sperm cells with the capacitated staining pattern $(53 \%)$ than the ionophore treated group $(28 \%)$, this difference did not increase the numbers of spermatozoa that bound to the zonae. In fact these two treatment groups did not differ in any aspect of sperm cell binding or subsequent exocytosis. The mean number $\left(9 \times 10^{6}\right)$ of sperm cells in suspension in the coculture group is slightly lower than the $10 \times 10^{6}$ sperm cells that were present in the ionophore and control wells. This difference in numbers between the two systems may partially explain the lack of increase in total numbers of spermatozoa binding for the coculture group, even though the percentage of capacitated sperm cells was higher. A minimum exposure time of spermatozoa with the OEC for capacitation to occur has not been established. Furthermore, no studies have as yet been done to determine whether there is an effect of the numbers of sperm cells placed in coculture and the subsequent percentage that undergo capacitation. Perhaps calcium shifts in the sperm cells of the coculture group were occurring after $4 \mathrm{~h}$ which caused changes in staining pattern, yet the sperm cells were not sufficiently capacitated to bind to the zonae.

In conclusion, stallion sperm cells in control medium, ionophore treatment or coculture could all bind to equine zonae and undergo the acrosome reaction. However, significantly more sperm cells bound in the ionophore and coculture groups. Coculture of sperm cells with oviduct epithelial cells resulted in a high percentage of spermatozoa showing the capacitated staining pattern. These sperm cells bound to frozen-thawed zonae in vitro and underwent acrosomal exocytosis.

This work was funded through the Harry M. Zweig Memorial Fund, Thornbrook Farms, and an NIH Physician Scientist Award (JEE) HDo0884. The authors thank P. G. Miller for technical support and J. Reyna for manuscript preparation.

\section{References}

Arns MJ, Webb GW, Johnson L, Martin J, Welsh T and Evans JW (1991) Zona pellucida-induced acrosome reactions in equine spermatozoa Journal of Reproduction and Fertility Supplement 44 738-739

Benau DA, McGuire EJ and Storey BT (1990) Further characterization of the mouse sperm surface zona-binding site with galactosyltransferase activity Molecular Reproductive Development 25 393-399
Bleil JD and Wasserman PM (1980) Mammalian sperm-egg interaction: identification of a glycoprotein in mouse egg zonae pellucidae possessing receptor activity for sperm Cell 20 873-882

Blue BJ, McKinnon AO, Squires EL, Seidel GE and Muscari KT (1989) Capacitation of stallion spermatozoa and fertilization of equine oocytes in vitro Equine Veterinary Journal $8111-116$

Cross NL, Morales P, Overstreet JW and Hanson FW (1988) Induction of acrosome reactions by the human zona pellucida Biology of Reproduction $\mathbf{3 8}$ 235-244

Ellington JE, Padilla AW, Vredenburg WL, Doughtery E and Foote RH (1991) Behavior of bull spermatozoa in bovine uterine tube epithelial cell co-culure Theriogenology 35 977-989

Ellington JE, Varner DD, Mathison P, Ignotz GG, Padilla AW, Miller PG, Marcucio RS and Ball BA (1992a) Interactions of stallion spermatozoa and mare uterine tube (oviduct) epithelial cells in a co-culture system Molecular Andrology 5 20-31

Ellington JE, Burghardt RC, Meyers-Wallen VN, Barhoumi R, Brinsko SP and Ball BA (1993) Cell-to-cell communication of equine uterine tube (oviduct) cells as determined by anchored cell analysis in culture Animal Reproduction Science 30 313-324

Fayrer-Hosken RA, Caudle AB and Shur BD (1991) Galactosyltransferase activity is restricted to the plasma membranes of equine and bovine sperm Molecular Reproductive Development 28 74-78

Florman HM and First NL (1988) The regulation of acrosomal exocytosis. I. Sperm capacitation is required for the induction of acrosome reactions by the bovine zona pellucida in vitro Developmental Biology $128453-463$

Florman HM and Storey BT (1982) Mouse gamete interactions: the zona pellucida is the site of the acrosome reaction leading to fertilization in vitro Developmental Biology 91 121-130

Florman HM, Tombes RM, First NL and Babcock DF (1989) An adhesion-associated agonist from the zona pellucida activates $\mathrm{G}$ protein-promoted elevations of internal $\mathrm{Ca}^{2+}$ and $\mathrm{pH}$ that mediate mammalian sperm acrosomal exocytosis Developmental Biology 135 133-146

Handrow RR, Boehm SK, Lenz RW, Robinson JA and Ax RL (1984) Specific binding of the glycosaminoglycan ${ }^{3} \mathrm{H}$-heparin to bovine, monkey and rabbit spermatozoa in vitro Journal of Andrology 5 51-63

Lathrop WF, Carmichael EP, Myles DG and Primakoff P (1990) cDNA cloning reveals the molecular structure of a sperm surface protein, $\mathrm{PH}-20$, involved in sperm-egg adhesion and the wide distribution of its gene among mammals Joumal of Cell Biology 111 2939-2949

Lee CN, Clayton MK, Bushmeyer SM, First NL and Ax RL (1986) Glycosaminoglycans in ewe reproductive tracts and their influence on acrosome reactions in bovine spermatozoa in vitro Journal of Animal Science 63 861-867

Lee MA and Storey BT (1989) Endpoint of first stage of zona pellucida-induced acrosome reaction in mouse spermatozoa characterized by acrosomal $\mathrm{H}^{+}$and $\mathrm{Ca}^{2+}$ permeability: population and single cell kinetics Gamete Research 24 303-326

Lenz RW, Bellin ME and Ax, RL (1983) Rabbit spermatozoa undergo an acrosome reaction in the presence of glycosaminoglycans Gamete Research 8 11-19

Miller CC, Fayrer-Hosken, RA, Timmons TM, Caudle AB and Dunbar BS (1991) Characterization of equine zona pellucida (ZP) glycoproteins by polyacrylamide gel electrophoresis and immunological techniques Biology of Reproduction 478 (Abstract)

Morales P, Cross NL, Overstreet JW and Hanson FW (1989) Acrosome intact and acrosome-reacted human sperm can initiate binding to the zona pellucida Developmental Biology 133 385-392

Nagai T and Moor RM (1990) Effect of oviduct cells on the incidence of polyspermy in pig eggs fertilized in vitro Molecular Reproductive Development $26377-382$

Neter J, Wasserman W and Kutner MH (1985) Applied Linear Statistical Models. Irwin, Homewood, IL

O'Rand MG and Fisher SJ (1987) Localization of zona pellucida binding sites on rabbit spermatozoa and induction of the acrosome reaction by solubilized zonae Developmental Biology 11955 1-559

Padilla AW and Foote RH (1991) Extender and centrifugation effects on the motility patterns of slow-cooled stallion spermatozoa Journal of Animal Science $693308-3313$

Palmer E, Bezard J, Magistrini M and Duchamp G (1991) In vitro fertilization in the horse. A retrospective study Journal of Reproductive Fertility 44 375-384

Parrish JJ, Susko-Parrish JL, Handrow RR, Simms MM and First NL (1989a) Capacitation of bovine spermatozoa by oviduct fluid Biology of Reproduction 40 1020-1025 
Parrish JJ, Susko-Parrish JL, Handrow RR, Ax RL and First NL (1989b) Effect of sulfated glycoconjugates on capacitation and the acrosome reaction of bovine and hamster spermatozoa Gamete Research 24 403-413

Peterson RN and Hunt WP (1989) Identification, isolation and properties of a plasma membrane protein involved in the adhesion of boar sperm to the porcine zona pellucida Gamete Research 23 103-118

Pollard JW, Plante C, King WA, Hansen PJ, Betteridge KJ and Suarez SS (1991) Fertilizing capacity of bovine sperm may be maintained by binding to oviductal epithelial cells Biology of Reproduction 44 102-107

Saling PM (1989) Mammalian sperm interaction with extracellular matrices of the egg Oxford Reviews of Reproductive Biology 11 339-388

Saling PM and Storey BT (1979) Mouse gamete interactions during fertilization in vitro Journal of Cell Biology 83 544-555

SAS (1982) SAS User's Guide: Statistics. SAS Institute, Cary, North Carolina

Varner DD, Ward CW, Storey BT and Kenney RM (1987) Induction and characterization of acrosome reaction in equine spermatozoa American Journal of Veterinary Research 48 138-139
Varner DD, Bowen JA and Johnson L (1992) Capacitation and acrosome reaction of equine spermatozoa by heparin Molecular Andrology 4 81-100

Voglmayr JK and Sawyer RF, Jr (1986) Surface transformation of ram spermatozoa in uterine, oviduct and cauda epididymal fluid in vitro journal of Reproductive Fertility 78 315-325

Wassarman PM (1988) Fertilization in mammals Scientific American (Dec) 78-84

Wheeler MB and Seidel GE, Jr (1987) Zona pellucida penetration assay for capacitation of bovine sperm Gamete Research 18 237-250

Yanagimachi R and Phillips DM (1984) The status of acrosomal caps of hamster spermatozoa immediately before fertilization in vivo Gamete Research 9 1-19

Yang X, Jiang $\mathrm{S}$ and Foote RH Bovine oocyte development following maturation in vitro with or without hormones and fertilization by sperm treated with heparin and calcium ionophore Molecular Reproductive Development (in press) 